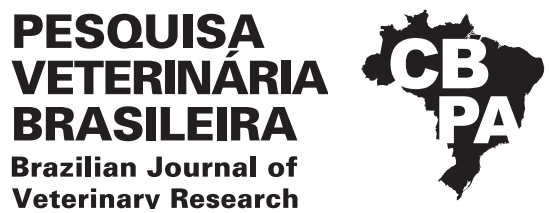

Pesq. Vet. Bras. 41:e06652, 2021

DOI: 10.1590/1678-5150-PVB-6652

Original Article

ISSN 0100-736X (Print)

Livestock Diseases

ISSN 1678-5150 (Online)

\title{
Effect of flunixin or ketoprofen in caudectomy by elastration in lambs: pain and neutrophil function ${ }^{1}$
}

\author{
Natali R. Schllemer ${ }^{2}$, Mariana M. Coneglian², Adriano F. Mendes², Desiree V. Pontarolo², \\ Angela M. Reck ${ }^{2}$, Alessandra M. Coelho ${ }^{2}$, Bruna Artner ${ }^{2}$ Adriano O.T. Carrasco ${ }^{2}$, \\ Meire Christina Seki ${ }^{2}$ and Heloisa G. Bertagnon ${ }^{2 *}$ (D)
}

\begin{abstract}
Schllemer N.R., Coneglian M.M., Mendes A.F., Pontarolo D.V., Reck A.M., Coelho A.M., Artner B., Carrasco A.O.T., Seki M.C. \& Bertagnon H.G. 2021. Effect of flunixin or ketoprofen in caudectomy by elastration in lambs: pain and neutrophil function. Pesquisa Veterinária Brasileira 41:e06652, 2021. Departamento de Medicina Veterinária, Universidade Estadual do Centro Oeste, Guarapuava, Avenida Prof. Dr. Simeão Camargo Varella de Sá 3, Guarapuava, PR 85040-080, Brazil. E-mail: hbertagnon@unicentro.br

Painful procedures can affect the function of innate immune cells, such as neutrophils and macrophages, increasing the risk of infectious diseases. The present work aimed to verify if the analgesics flunixin meglumine or ketoprofen can attenuate the pain/discomfort of newborn lambs submitted by elastration tail docking and thereby avoid the impairment of blood granulocytes function. Twenty-one neonate lambs were divided into three treatments: the control group ( $n=7)$, not subjected to caudectomy; the flunixin group $(n=7)$, subjected to caudectomy under local anesthesia and analgesia with two doses of flunixin meglumine; and the ketoprofen group $(\mathrm{n}=7)$, subjected to caudectomy under local anesthesia and two doses of ketoprofen. Pain indicators were observed by pain posture score (PS), the number of vocalizations $(\mathrm{V})$, frequency of the movement of the ears (EF), and respiratory rates (RR), observed by a 10 minutes videos for each time points: $-15 \mathrm{~min}, 6 \mathrm{~h}, 48 \mathrm{~h}$, and $144 \mathrm{~h}$. At the same time points, the reactive oxygen species (ROS) production and phagocytosis of blood granulocytes were measured by flow cytometry. At $6 \mathrm{~h}$ after caudectomy, there was a pain indicator increase (RR, V, and PS), a blood granulocyte percentage increase, and a granulocytes phagocytosis reduction for both groups. At $48 \mathrm{~h}$, the ketoprofen group spend more time in pain posture and, at $144 \mathrm{~h}$, they exhibited a ROS production granulocyte reduction without signs of pain. We conclude the flunixin meglumine and ketoprofen did not prevent the acute pain/ discomfort caused by caudectomy, because the groups showed a pain behavior and impaired of the innate immune response however, the flunixin meglumine was effective in controlling the chronic pain and their effects on blood granulocytes function in compare ketoprofen.
\end{abstract}

INDEX TERMS: Flunixin, ketoprofen, caudectomy, elastration, lambs, neutrophils, tail docking, phagocytosis, analgesia.

RESUMO.- [Efeito de flunixin ou cetoprofeno em cordeiras submetidas a caudectomia por elastração: dor e função neutrofílica.] Procedimentos dolorosos podem afetar a função das células imunes inatas como neutrófilos e macrófagos, aumentando o risco de ocorrer doenças infeciosas. Desta maneira, o presente trabalho pretendeu verificar se os

\footnotetext{
${ }^{1}$ Received on December 15, 2020.

Accepted for publication on January 4, 2021.

${ }^{2}$ Departamento de Medicina Veterinária (Devet), Universidade Estadual do Centro-Oeste (Unicentro), Avenida Prof. Dr. Simeão Camargo Varella de Sá 3, Guarapuava, PR 85040-080, Brazil. *Corresponding author: hbertagnon@unicentro.br
}

analgésicos flunixin meglumine ou cetoprofeno conseguem atenuar a dor/desconforto de cordeiros neonatos submetidos a caudectomia por elastração, evitando assim o comprometimento da função dos granulócitos sanguíneos. Para tanto 21 cordeiras foram aleatoriamente divididas em três tratamentos: grupo controle ( $\mathrm{n}=7$ ) não submetido a caudectomia, grupo flunixin $(\mathrm{n}=7)$ submetido a caudectomia precedida por anestesia local e duas doses de flunixin meglumine, e cetoprofeno $(n=7)$ submetido a caudectomia precedida por anestesia local e duas doses de cetoprofeno. Mensurou-se os indicadores de dor/desconforto após caudectomia por observações de escore de postura de dor (EP), número de vocalizações 
(V), frequência de movimentar as orelhas (FO) e frequência respiratória (FR), observados em vídeos de 10 minutos nos momentos - 15 min e 6, 48 e $144 \mathrm{~h}$. Nos mesmos momentos, avaliou-se a as funções de produção de espécies reativas de oxigênio (ERO) e de fagocitose por granulócitos sanguineos em citometria de fluxo. Notou-se aumento dos indicadores de dor (FR, de V e de EP), da porcentagem dos granulócitos sanguíneos e redução da eficiência de fagocitose em ambos os grupos as $6 \mathrm{~h}$. As $48 \mathrm{~h}$, os animais do grupo cetoprofeno ainda apresentava mais tempo em postura de dor que os demais grupos e as $144 \mathrm{~h}$, apresentou redução da produção ERO por granulócitos. Tais achados permitem concluir que tanto o flunexin meglumine como o cetoprofeno não preveniram dor/ desconforto agudo promovido pela elastração, pois os dois grupos manifestaram comportamento de dor e redução da resposta imune inata. Ainda, 0 analgésico flunixin meglumine foi efetivo em controlar a dor mais tardia e seus efeitos na função de granulócitos sanguíneos em comparação ao cetoprofeno.

TERMOS DE INDEXAÇÃO: Flunixin, cetoprofeno, cordeiros, caudectomia, elastração, neutrófilos, descola, fagocitose, analgesia.

\section{INTRODUCTION}

Caudectomy is a husbandry procedure performed on sheep, which is beneficial to production but may cause pain and discomfort for the animal (Grant 2004). New perspectives on the consciousness of animals and their well-being have questioned the procedures about the real benefits to the practice of caudectomy (Fisher et al. 2004). To avoid animal pain and stress and improve animal welfare, some countries had prohibited the caudectomy while others have conducted research examining the potential for analgesic options for caudectomy (Paull et al. 2007).

There are different techniques and anesthetics and nonsteroidal anti-inflammatory drugs (NSAID) protocol for sheep pain relief; however, there is no conclusion about the ideal protocol (Kent et al. 2004, Marini et al. 2017). The elastration caudectomy is usually the most frequently used method in Brazil (Aro et al. 2007), Australia (Grant 2004), and New Zealand (Fisher et al. 2004). It involves a rubber ring placed around the tail of the animal. This procedure causes ischemia and necrosis of the tail that usually occurs around 7 to 30 days following the procedure (Grant 2004, Aro et al. 2007).

The ischemia and the continuous tissue damage in the region stimulate the local pain receptors for up to 4 days. This induces physiological changes responsible for increase the pain threshold, decreases the immunity and the productive performance of the animals. The main effect is observed on cortisol serum and the innate immunity. There was an increase in blood neutrophils and decreases their functions, which could increase the risk of infectious disease after the painful procedures (Bellinazzi et al. 2013, Marini et al. 2017, Small et al. 2018).

Therefore, research to develop efficient analgesic protocols to perform caudectomy via elastration is crucial to promote animal wellness and health, but unfortunately, the most studies about caudectomy analgesic protocols evaluate the effects of pain in lambs only for three days after the procedure (Grant 2004, Kent et al. 2004, Marini et al. 2017). Although, the pain identification in ruminants can be challenging because these species do not demonstrate clearly the pain (Millman 2013).
Although plasma cortisol increases under various physiological and pathophysiological conditions, previous studies used this parameter in conjunction with observations of behavior and posture to assess pain and distress during and after the painful procedures. Marini et al. (2017) graded pain scores based on local reactions on caudectomy site and behavioral observations. Paull et al. (2007), identified the surgical caudectomy pain by serum cortisol levels measurement and by abnormal postures, such as kyphotic posture and a rigid gait. Guesgen et al. (2016) observed the ears movements as a behavioral pain indicator in sheep submitted a caudectomy by elastration. The respiratory and cardiac frequencies as well as body temperature, are physiological parameters that may be used as indicators of stress; however, they are easily influenced by the environment and by manipulation of the lambs (Millman 2013).

Among the different analgesic protocols that have been studied for caudectomy and castration by elastration, regional infiltrative anesthesia with $2 \%$ lidocaine is a procedure that induces effective analgesia for approximately $2 \mathrm{~h}$ (Ballou et al. 2013, Bellinazzi et al. 2013). The use of non-steroidal antiinflammatory drugs (NSAIDs), such as ketoprofen, flunixin meglumine, meloxican or carprofen, administered as a single dose, can prolong and amplify the analgesic effect for up to 24h (Paull et al. 2007, Marini et al. 2017, Sousa et al. 2019). Since the discomfort generated by this procedure can persist for more than 24h (Kent et al. 2004) it is often considered that the use of two doses of these drugs can perpetuate the analgesia for a period greater than 1 day.

Because rubber ring elastration is the most common procedure for tail docking that is employed by veterinarians and sheep farmers (Aro et al. 2007) and flunixin meglumine and ketoprofen were the NSAIDs most used by previous studies (Paull et al. 2007, 2008, Marini et al. 2017, Straticò et al. 2018) and are the most used drugs to prevent pain in ruminants in Brazil, we believed the analgesics flunixin meglumine or ketoprofen can attenuate the pain/discomfort of newborn lambs submitted by elastration tail docking and thereby avoid the impairment of blood granulocytes function. The objective of this study was to evaluate the pain and the impairment of blood granulocytes function in lambs submitted to by elastration tail docking with two different analgesics protocols: local anesthesia and flunixin meglumine or local anesthesia and ketoprofen.

\section{MATERIALS AND METHODS}

Experimental design. This project was approved by the animal ethics committee, CEUA/Unicentro, under the protocol number, 038/2016. The experiment was conducted in May 2018. Twentyone healthy lambs were used in this study. One week before the experiment, animals were group housed with their mothers to indoor, during the evening (6:00 p.m.) when received corn silage, and were moved to the oatmeal pasture along the morning (9:00 a.m.), and had fresh water available ad libtum at all times. On study days a flock of ewes with lambs 'at foot', of 2-4 weeks of age and a mean weight of $3.8 \pm 0.5 \mathrm{~kg}$, were brought smaller pens $(4 \times 3 \mathrm{~m})$ separate from their mothers; however, they were able to maintain visual, olfactory, and/ or auditory contact with them, and spray marked numerically. Each pen had seven lambs of the same treatment group. After a period of up to $20 \mathrm{~min}$ to become familiar with this environment, lambs were taken from the observation pen, placed in a supine position 
in a 'marking' cradle, and restrained by locking their hocks into stirrups on either side of the cradle. From this position husbandry procedures were performed.

The lambs were divided into three homogeneous groups according to their weight and age. In the flunixin group (n=7), the caudectomy was performed by applying the elastration ring between the fourth and fifth caudal vertebrae. Previous, subcutaneous regional anesthesia was made in the site to be elastrated via $22 \mathrm{G}$ needle with $1 \mathrm{ml}$ of $2 \%$ lidocaine without using a vasoconstrictor (Lidove ${ }^{\circledR}$, lidocaine, Brasvet, RJ, Brazil). Additionally, two doses of flunixin meglumine $(2.2 \mathrm{mg} / \mathrm{kg}, \mathrm{IM})$ (Flumax ${ }^{\circledR}$, flunixin meglumine, JA animal health, PR, Brazil), were administered with a 24-h interval between them. The first dose was administered immediately after the procedure. In the ketoprofen group ( $n=7)$, the animals were subjected to the same caudectomy procedure and the same regional anesthesia. They received two doses of ketoprofen $\left(3.0 \mathrm{mg} / \mathrm{kg}\right.$, IM) (Ketofen ${ }^{\circledR}$, ketoprofen, Merial, SP, Brazil) with a 24-h interval between them. The first dose was administered immediately after the procedure. Finally, in the control group ( $n=7)$, the caudectomy procedure was simulated by applying pressure on the elastration site using hands, and a $0.9 \% \mathrm{NaCl}$ solution was applied instead of anesthetic and analgesic agents (in the same volume and route). There wasn't a caudectomy group without analgesia because the Brazilian animal ethics committee does not allow.

The procedure took approximately $1 \mathrm{~min}$ to complete and none of the animals received extra doses of analgesics, nor present any complications in the caudectomy region. To verify if the technique could affect the animal's well-being, the pain measurements and the blood granulocytes percentage and their functions were performed at the following timepoints: -15 min (15 minutes before the procedure), $6 \mathrm{~h}, 48 \mathrm{~h}$, and $144 \mathrm{~h}$ after the procedure. For this analysis, the lambs stayed in their pens until 6 hours after the procedures, and then they and their mothers were moved to the pasture. On this day, they were fed $1 \mathrm{~h}$ before caudectomy so that feeding would not coincide with behavioral observation. On the other days, behavioral observation and blood collection were made before they were moved to the pasture.

Blood granulocyte evaluations. The blood was collected via 20 gauge needles into $4.5 \mathrm{~mL}$ vacutainers containing heparin as an anticoagulant by puncturing the external jugular vein. The percentage of granulocytes and their functions including phagocytosis and the intracellular production of reactive oxygen species (ROS) were measured by the flow cytometry technique, as descripted by Kampen et al. (2004). For this evaluation, $100 \mu \mathrm{l}$ of blood was incubated at $37^{\circ} \mathrm{C}$ for 30 minutes with $2 \mu \mathrm{l}$ of Staphylococcus aureus conjugated using Alexa Fluor 594 (S23372, Life Technology, Brazil) and with $200 \mu \mathrm{L}$ of 2',7'-dichlorodihydrofluorescein diacetate (DCFH-DA-D399, Life Technology, SP, Brazil). Subsequently, the reactions were interrupted with the addition of $2,000 \mu \mathrm{l}$ of ice-cold ethylenediaminetetraacetic acid solution ( $3 \mathrm{mM}$ EDTA). The red blood cells were subjected to osmotic lysis three times. The samples were then resuspended in phosphate buffered saline (PBS) and evaluated in the flow cytometer (Accuri C6 - Becton Dickinson, SP, Brazil), counting 20,000 events with the Cell Quest software (Becton Dickinson Immunocytometry SystemsTM) (Kampen et al. 2004).

The cell populations were evaluated using the Flowjo program (v.10.07, Treestar, CA, USA), and the granulocytes were separated based on cell size dispersion (FSC) and granularity (SSC). In the granulocyte gate, the oxidative metabolism (production of stimulated ROS) and the phagocytosis capacity were analyzed. The percentage of the total number of granulocytes performing each function (\%) and their efficiency in performing them were measured via fluorescence intensity (FI). The negative control was realized by the cells that were not labeled with a fluorochrome, and the positive control, by cells labeled with each fluorochrome (Fig.1) (Kampen et al. 2004).

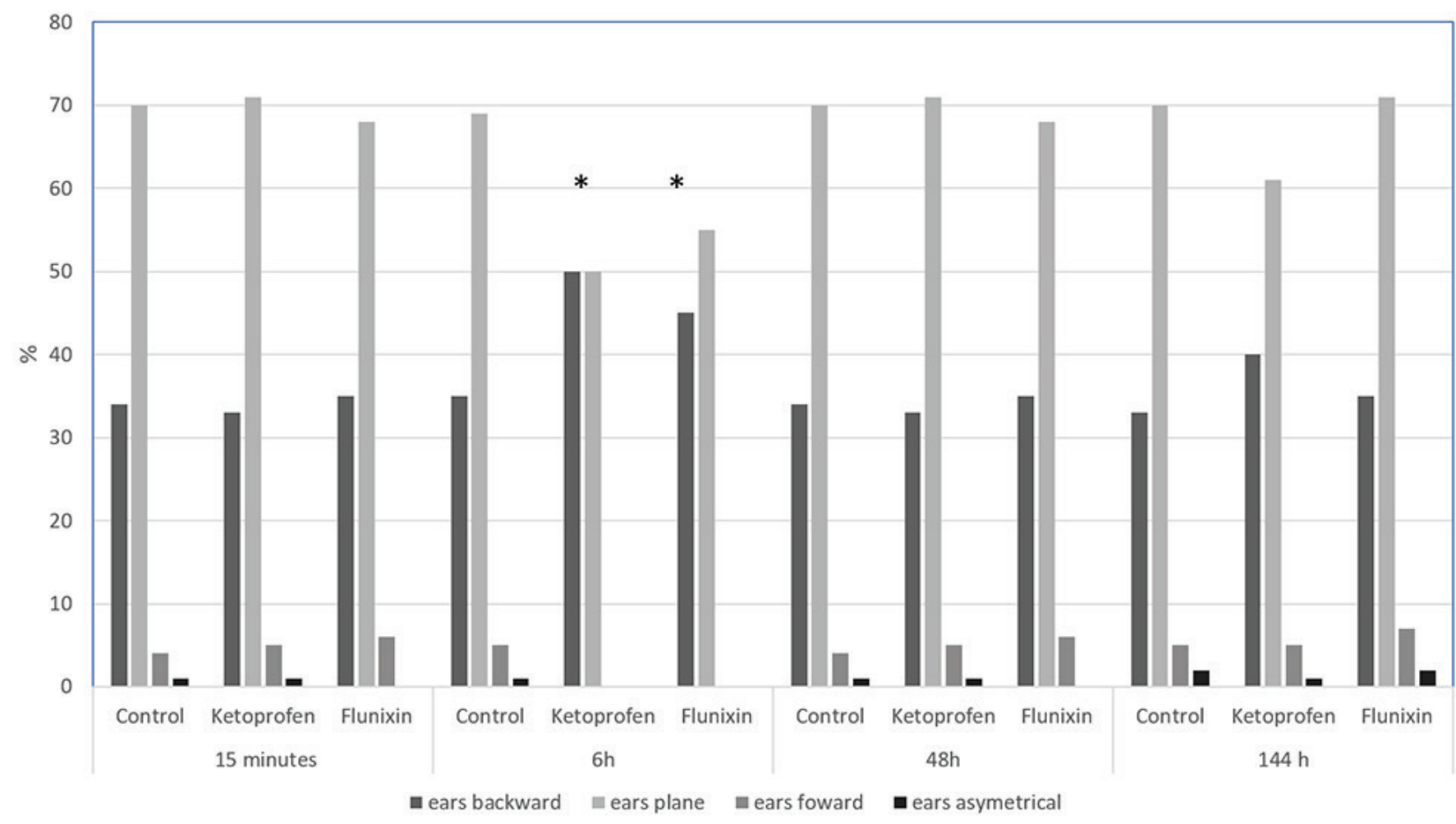

Fig.1. Time spend of each ears position in lambs according the analgesic protocols for caudectomy. Significance difference $(*)$. Tukey test, $P<0.05$. 
Pain identification. The pain identification was analyzed by video recording the lambs housed in their pens for 10 minutes at each time point. The camera remained positioned outside the animal pens, approximately 1 meter of distance, to not disturb them. Beyond the camera operator, a blinded observer to the treatment was responsible for assessing the respiratory rates (RR) of the animals, measured by visually inspecting the thoracic movement.

The behavioral analysis was comprised of pain posture score (PS). The vocalizations (V), and ears positions (EF) frequency were recorded by counting the number of times that the animals vocalized or positioned their ears backward. The PS was graded according to the scale proposed by Lomax et al. (2013). The scores from 0 to 3 were graded as Table 1 . For all the behavior parameters, a trained observer (experienced animal scientist 'blind to treatment') analyzed the videos.

Therefore, the proportion of the total time the lamb spends its ears in each position (ears plane, ears forward, ears backway or ears asymmetric) and the total time the lamb spend in an abnormal pain posture was calculated and analyzed (Lomax et al. 2013, Guesgen et al. 2016).

Statistical analysis. For the statistical analysis, the data associated with the RR, EF, V, percentage of granulocytes, and the percentage of granulocytes functions were normally distributed. For all the treatments, the data were analyzed for time and treatment interaction using multivariable, parametric analyses of variance (repeated measures ANOVA), and Tukey's post tests. The PS and efficiency of the granulocyte functions were assessed via nonparametric ANOVA and Dunn tests. The total time in normal or abnormal posture was calculated to $100 \%$ of time observation. A significant difference was considered when $P \leq 0.05$ using the software, GraphPad InStat (GraphPad Software, La Jolla, CA, USA).

\section{RESULTS}

The RR, V, EF, and PS results are presented in Table 2. There was a time interaction $(P=0.0001)$ at $48 \mathrm{~h}$ time point for respiratory rates. It had an increase for all groups. There was a treatment interaction at $6 \mathrm{~h}$ for animals from caudectomy groups, they exhibited an increase in the RR $(P=0.01)$ and $\mathrm{V}(P=0.02)$ in compared to the control group. For time interaction, we observed a higher $\mathrm{V}(P=0.003)$ for animals from caudectomy groups at $6 \mathrm{~h}$ in comparison the other time point. There was a treatment interaction at $6 \mathrm{~h}$ nd $48 \mathrm{~h}$ for animals from caudectomy groups, they exhibited an increase in PS $(P=0.03$ and $P=0.03)$ in compared to the control group. For time interaction, we observed a higher PS $(P=0.05$ and $P=0.05$ ) for animals from caudectomy groups at $6 \mathrm{~h}$ and $48 \mathrm{~h}$ in comparison the other time point.

Table 1. Ethogram used for lamb pain posture score (PS)*

\begin{tabular}{cl}
\hline Score & \multicolumn{1}{c}{ Pain posture } \\
\hline 0 & $\begin{array}{l}\text { No pain-related behavior. } \\
\text { Mild abnormalities in the posture, gait, or behavior such as mild kyphosis without hyperextension of the hindlegs, ventral recumbency with } \\
\text { the hindlegs partially extended, or mild stiffness in the gait without overt limping or leg dragging. }\end{array}$ \\
2 & $\begin{array}{l}\text { Moderate abnormalities in the posture, gait, or behavior such as 'statue standing' with the head positioned downwards and prominent kyphosis, } \\
\text { moderate stiffening or slowing of the gait or hyperextension and/or abduction of the hindlegs, or ventral recumbency with the hindlegs fully extended. }\end{array}$ \\
3 & $\begin{array}{l}\text { Display of severe abnormalities in the posture, gait, or behavior such as displaying marked agitation with twisting or writhing, high frequency } \\
\text { of postural changes from lying down to kneeling or standing, distressed vocalization, lying down in a lateral or prostrate position, kneeling, } \\
\text { dog sitting, tremors, shaking, or lip curling. }\end{array}$
\end{tabular}

*(Lomax et al. 2013)

Table 2. Pain identification in lambs according the analgesic protocols for caudectomy

\begin{tabular}{|c|c|c|c|c|c|c|c|c|c|c|}
\hline \multirow{2}{*}{ Item } & \multirow{2}{*}{ Group } & \multicolumn{2}{|c|}{$-15 \min$} & \multicolumn{2}{|c|}{$6 \mathrm{~h}$} & \multicolumn{2}{|c|}{$48 \mathrm{~h}$} & \multicolumn{2}{|c|}{$144 \mathrm{~h}$} & \multirow{2}{*}{$P$ time } \\
\hline & & $\mathrm{M} / \mathrm{ME}$ & MSE/CI & $\mathrm{M} / \mathrm{ME}$ & MSE/CI & $\mathrm{M} / \mathrm{ME}$ & MSE/CI & $\mathrm{M} / \mathrm{ME}$ & MSE/CI & \\
\hline \multirow[t]{4}{*}{$\mathrm{RR}$} & Control & $47.42 \mathrm{bA}$ & 4.22 & $44.57 \mathrm{bB}$ & 5.61 & $135.71 \mathrm{aA}$ & 16.96 & $69.14 \mathrm{bA}$ & 7.58 & 0.0001 \\
\hline & Ketoprofen & $49.00 \mathrm{bA}$ & 4.81 & $60.28 \mathrm{bA}$ & 5.23 & $114.00 \mathrm{aA}$ & 17.92 & $70.85 \mathrm{bA}$ & 16.54 & 0.0001 \\
\hline & Flunixin & $53.14 \mathrm{bA}$ & 8.01 & $65.71 \mathrm{bA}$ & 5.26 & $125.28 \mathrm{aA}$ & 15.18 & $63.42 \mathrm{bA}$ & 12.95 & 0.0001 \\
\hline & $P$ treatment & 0.78 & & 0.01 & & 0.66 & & 0.60 & & \\
\hline \multirow[t]{4}{*}{$\mathrm{V}$} & Control & $0.0 \mathrm{aA}$ & 0.0 & $0.16 \mathrm{aB}$ & 0.16 & $0.16 \mathrm{aA}$ & 0.16 & $1.50 \mathrm{aA}$ & 1.14 & 0.28 \\
\hline & Ketoprofen & $0.0 \mathrm{bA}$ & 0.0 & $17.00 \mathrm{aA}$ & 5.48 & $2.57 \mathrm{bA}$ & 1.54 & $3.00 \mathrm{bA}$ & 2.68 & 0.0005 \\
\hline & Flunixin & $1.0 \mathrm{bA}$ & 0.5 & $16.33 \mathrm{aA}$ & 4.63 & $0.33 \mathrm{bA}$ & 0.33 & $0.33 \mathrm{bA}$ & 0.21 & 0.0003 \\
\hline & $P$ treatment & 0.20 & & 0.02 & & 0.19 & & 0.59 & & \\
\hline \multirow[t]{4}{*}{$\mathrm{EF}$} & Control & $6.83 \mathrm{aA}$ & 3.27 & $2.66 \mathrm{aA}$ & 0.95 & $3.50 \mathrm{aA}$ & 0.99 & $4.50 \mathrm{aA}$ & 1.23 & 0.32 \\
\hline & Ketoprofen & $4.00 \mathrm{aA}$ & 2.06 & $1.40 \mathrm{aA}$ & 0.57 & $3.71 \mathrm{aA}$ & 0.96 & $4.85 a A$ & 1.52 & 0.26 \\
\hline & Flunixin & $2.28 \mathrm{aA}$ & 1.46 & $0.71 \mathrm{aA}$ & 0.56 & $2.42 \mathrm{aA}$ & 1.02 & $3.71 \mathrm{aA}$ & 1.23 & 0.42 \\
\hline & $P$ treatment & 0.41 & & 0.17 & & 0.22 & & 0.82 & & \\
\hline \multirow[t]{4}{*}{ PS* } & Control & $0.0 \mathrm{aA}$ & $0.0-0.0$ & $0.0 \mathrm{aB}$ & $0.0-0.0$ & $0.0 \mathrm{aA}$ & $0.0-0.0$ & $0.0 \mathrm{aA}$ & $0.0-0.0$ & 0.36 \\
\hline & Ketoprofen & $0.0 \mathrm{bA}$ & $0.0-0.0$ & $1.0 \mathrm{aA}$ & $0.0-1.0$ & $1.0 \mathrm{aA}$ & $0.0-1.0$ & $0.0 \mathrm{bA}$ & $0.0-0.0$ & 0.05 \\
\hline & Flunixin & $0.0 \mathrm{bA}$ & $0.0-0.0$ & $1.0 \mathrm{aA}$ & $0.12-1.2$ & $1.0 \mathrm{aA}$ & $0.12-1.2$ & $0.0 \mathrm{bA}$ & $0.0-0.8$ & 0.05 \\
\hline & $P$ treatment & 0.99 & & 0.03 & & 0.03 & & 0.7 & & \\
\hline
\end{tabular}

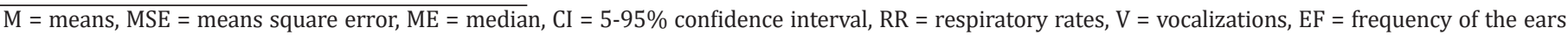

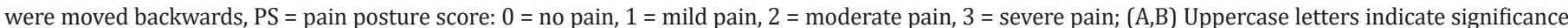
difference between groups, $(\mathrm{a}, \mathrm{b})$ lowercase letters indicate significance difference between the time for each group; Tukey test, $P<0.05,{ }^{*}$ Dunn test, $P<0.05$. 
The total time the lambs spend with the ears in each position is in Figure 2. There was a treatment and a time interaction at $6 \mathrm{~h}$ for animals from caudectomy groups for these pain behaviour. The animals spend more time with ears backward in compared to the control group $(P=0.04)$ and, in comparison to the others time points $(P=0.04)$.

The total time the lambs spend in abnormal pain posture is in Figure 3 and Figure 4. There was also a treatment and a time interaction for caudectomies groups for these pain behaviour. The animals from flunixin group spend more time in abnormal pain posture than control group at $6 \mathrm{~h}(P=0.02)$, and this time point was higher than the others time points $(P=0.02)$. The lambs from ketoprofen group spend more time in abnormal pain posture than control group at $6 \mathrm{~h}(P=0.02)$ and than control and flunixin group at $48 \mathrm{~h}(P=0.05)$. Also, these time points were higher than $-15 \mathrm{~min}$ and $144 \mathrm{~h}(P=0.02$ and $P=0.05)$

The granulocyte's blood percentage and their functions are presented in Table 3 and 4 . At $6 \mathrm{~h}$, there was treatment interaction $(P=0.05)$, the caudectomy groups had an increase of the granulocyte's blood percentage. In the same time point, there was a decrease of granulocytes phagocytosis efficiency

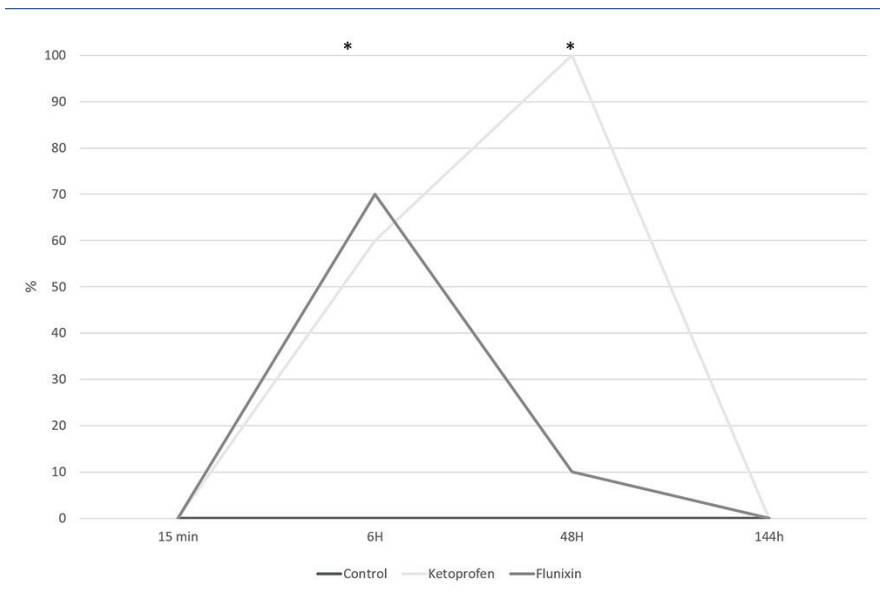

Fig.2. Time spend in abnormal posture in lambs according the analgesic protocols for caudectomy. Significance difference $\left(^{*}\right)$. Tukey test, $P<0.05$. (fluorescence intensity) for ketoprofen group $(P=0.005)$ and for flunixin group $(P=0.0008)$ in compared to $-15 \mathrm{~min}$ and $144 \mathrm{~h}$.

There was no treatment interaction or time interaction for granulocytes ROS production efficiency, but there was a time interaction at $144 \mathrm{~h}$ for the ketoprofen group. There was a reduction in the granulocytes ROS production percentage in comparison to $6 \mathrm{~h}$ and $48 \mathrm{~h}(P=0.03)$, without treatment interaction.

\section{DISCUSSION}

We observed the analgesic protocol (flunixin meglumine or ketoprofen) did not prevent the acute pain or discomfort experienced by lambs after a rubber ring caudectomy, because there was a reduction in granulocytes phagocytosis at $6 \mathrm{~h}$ after the procedure and an increase of pain behavior at $6 \mathrm{~h}$ and $48 \mathrm{~h}$ after the procedure. Also, we believe the ketoprofen was not effective in control the chronic pain because this group had a decrease of granulocytes ROS production at $144 \mathrm{~h}$.

Painful and stressful conditions induce endogenous production of cortisol, adrenaline, inflammatory cytokines, and inflammatory proteins that interfere with leukocyte chemotaxis into the inflamed areas. As consequence, there was an increase of neutrophils count in the blood circulation with a lower efficiency of phagocytosis and ROS production. As neutrophils are the main granulocyte population of the blood, their lower function indicates impaired of the innate immune system (Tornquist \& Rigas 2010).

Although studies conducted on caudectomy performed by elastration are scarce, Paull et al. (2007) and Lomax et al. (2013) found that analgesia induced by a local anesthetic in combination with NSAIDs did not lead to an increase in the serum cortisol levels or pain-related behavioral signs during the first $24 \mathrm{~h}$ after the procedure. However, when no analgesic protocol is followed, Kent et al. (2004) found an increased secretion of serum cortisol for up to 3 days after the elastration procedure.

According to Paull et al. (2007) and Marini et al. (2017), flunixin meglumine reduced the plasma cortisol levels at the $30 \mathrm{~min}$ and $6 \mathrm{~h}$ time points after surgical caudectomy, but an elevation in plasma cortisol levels was observed at the $12 \mathrm{~h}$ time point after the procedure; on the other hand, ketoprofen
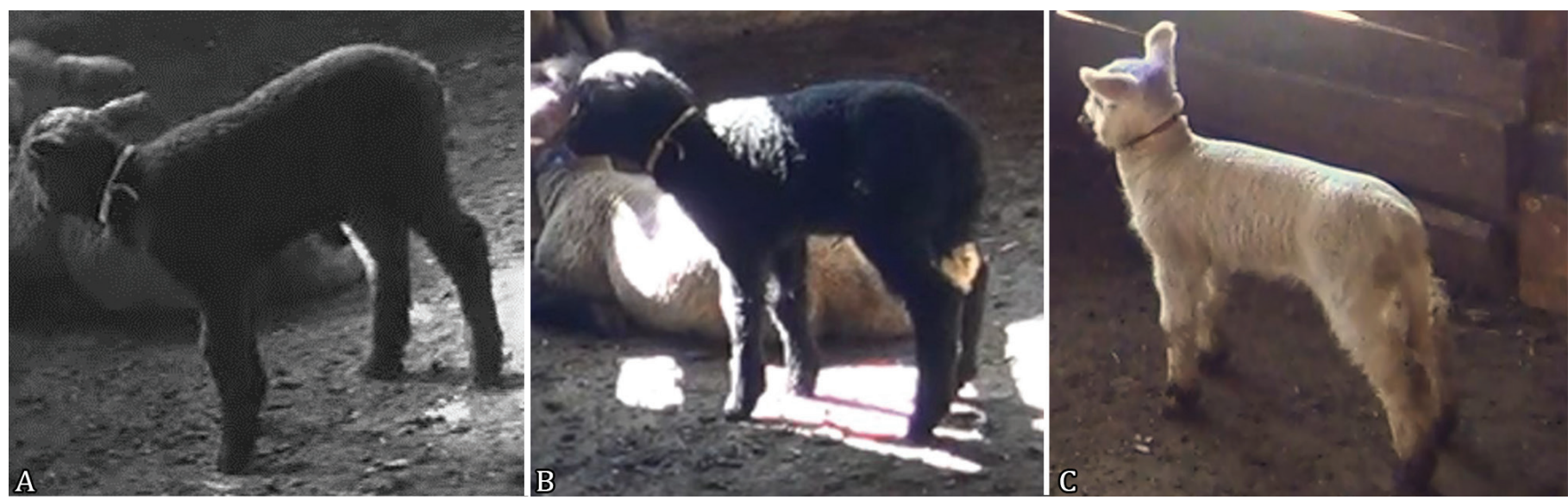

Fig.3. Ethogram used for lamb pain posture score (PS) after elastration caudectomy. (A) Score $0=$ normal posture, (B) Score $1=$ mild kyphosis without hyperextension of the hindlegs, (C) Score 2 = "statue standing' with the head positioned downwards, and hyperextension of the hindlegs. 
prevented the elevation of plasma cortisol levels for between 6 to 48 hours after the procedure.

Similar to caudectomy by elastration, orchiectomy by elastration also produces chronic pain and is a stress model that is more frequently used than caudectomy (Mellor et al. 2000). In these models, there are varied results regarding the peak level of serum cortisol and the neutrophilic count and their functions. In these studies, was found that castration by elastration performed without following analgesic protocol increased serum cortisol secretion and no interference on neutrophil functions. Ballou et al. (2013) found increased serum cortisol, neutrophilia, and impaired neutrophil functions at the 24 and $72 \mathrm{~h}$ time points after the procedure with or without analgesia.
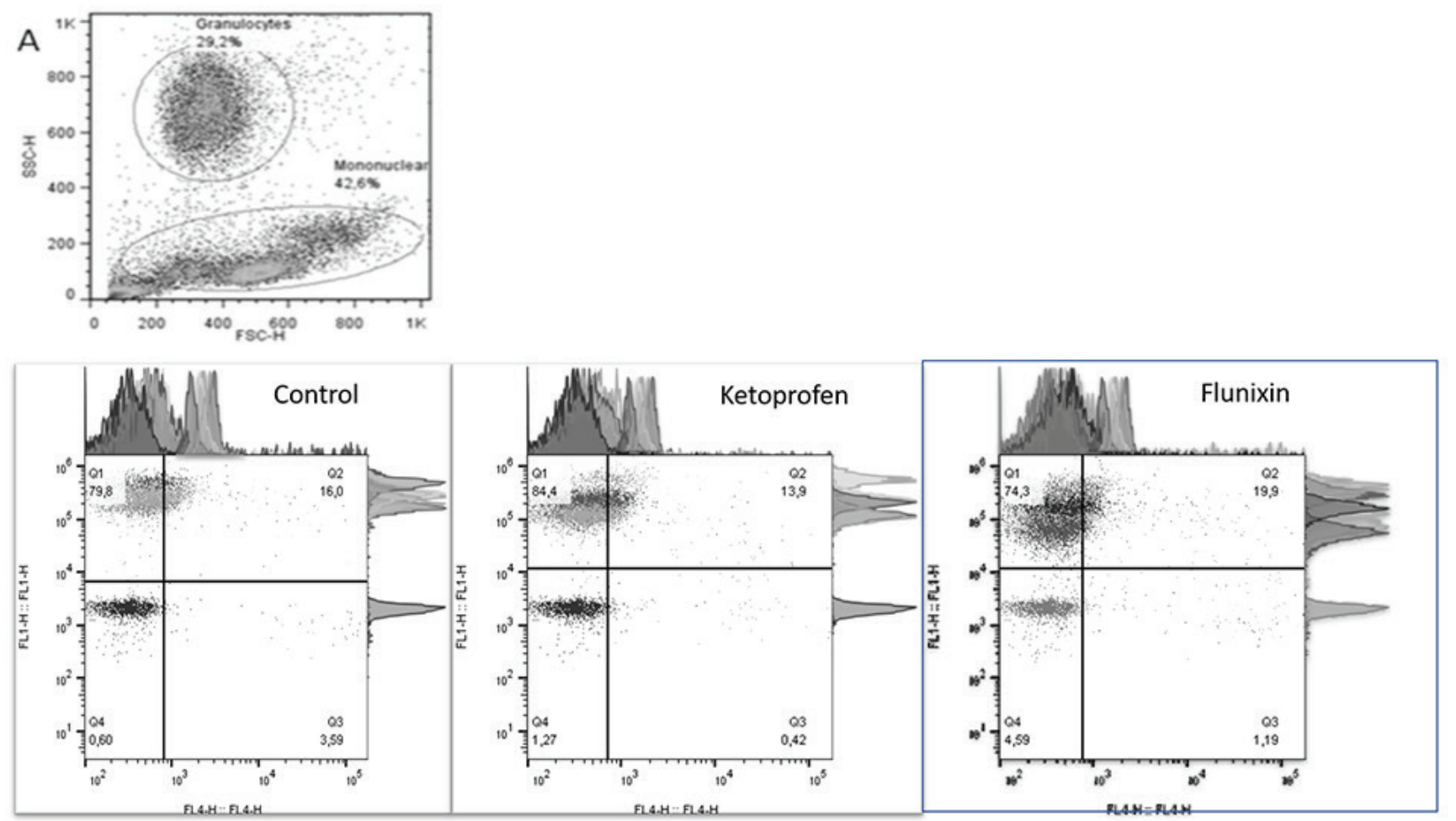

Fig.4. Graphical representation of leukocytes by flow cytometry. Dot plot depicting separation of leukocyte population into mononuclear cells and granulocytes (A). Dot plot and histogram of granulocyte that produced 2,7-dichlorodihydrofluorescein (Q1 = DCFH- in FL1H-F1-H) and phagocyted Staphylococcus aureus (Q3 = Alexa fluor 594-in FL4H-FL4H) in lambs according the analgesic protocols for caudectomy at $6 \mathrm{~h}$ after the caudectomy. Light grey histogram were the cells without labeling, considered the negative controls, and dark grey histogram were the cells labeling, considered positive $(\mathrm{Q} 2$ = granulocyte that do not produced 2,7-dichlorodihydrofluorescein and do not phagocyted Staphylococcus aureus, and Q4 = granulocyte that produced 2,7-dichlorodihydrofluorescein and phagocyted Staphylococcus aureus).

Table 3. Percentage of blood granulocytes and their functions in lambs according the analgesic protocols for caudectomy

\begin{tabular}{|c|c|c|c|c|c|c|c|c|c|c|}
\hline \multirow{2}{*}{ Item } & \multirow{2}{*}{ Group } & \multicolumn{2}{|c|}{$-15 \min$} & \multicolumn{2}{|c|}{$6 \mathrm{~h}$} & \multicolumn{2}{|c|}{$48 \mathrm{~h}$} & \multicolumn{2}{|c|}{$144 \mathrm{~h}$} & \multirow{2}{*}{$P$ time } \\
\hline & & $M$ & MSE & M & MSE & M & MSE & M & MSE & \\
\hline \multirow[t]{4}{*}{ \% Granulocytes } & Control & $31.08 \mathrm{aA}$ & 2.83 & $33.8 \mathrm{aB}$ & 5.16 & $36.89 \mathrm{aA}$ & 3.89 & $32.71 \mathrm{aA}$ & 2.81 & 0.76 \\
\hline & Ketoprofen & $27.45 \mathrm{bA}$ & 4.71 & $43.95 \mathrm{aA}$ & 5.01 & 37.9abA & 2.22 & $28.00 \mathrm{bA}$ & 4.62 & 0.05 \\
\hline & Flunixin & $21.06 \mathrm{bA}$ & 1.1 & $40.14 \mathrm{aA}$ & 7.04 & $30.42 \mathrm{abA}$ & 2.44 & $21.43 \mathrm{bA}$ & 0.97 & 0.008 \\
\hline & $P$ treatment & 0.12 & & 0.05 & & 0.17 & & 0.08 & & \\
\hline \multirow{4}{*}{$\begin{array}{l}\text { (\%) Granulocyte } \\
\text { phagocytosis }\end{array}$} & Control & $54.1 \mathrm{aA}$ & $1, .8$ & $55.82 \mathrm{aA}$ & 3.52 & $61.97 \mathrm{aA}$ & 3.97 & $55.48 \mathrm{aA}$ & 3.85 & 0.21 \\
\hline & Ketoprofen & $54.9 \mathrm{aA}$ & 2.83 & $58.85 \mathrm{aA}$ & 1.58 & $62.86 \mathrm{aA}$ & 2.71 & $54.44 \mathrm{aA}$ & 2.92 & 0.15 \\
\hline & Flunixin & $56.51 \mathrm{aA}$ & 0.98 & $58.9 \mathrm{aA}$ & 2.9 & $63.94 \mathrm{aA}$ & 3.29 & $62.7 \mathrm{aA}$ & 5.56 & 0.19 \\
\hline & $P$ treatment & 0.68 & & 0.67 & & 0.91 & & 0.34 & & \\
\hline \multirow[t]{4}{*}{ (\%) Granulocytes ROS } & Control & $53.92 \mathrm{aA}$ & 2.18 & $55.51 \mathrm{aA}$ & 2.82 & $61.65 \mathrm{aA}$ & 3.90 & $53.51 \mathrm{aA}$ & 3.8 & 0.23 \\
\hline & Ketoprofen & $54.08 \mathrm{abA}$ & 4.41 & $59.98 \mathrm{bA}$ & 1.99 & $63.38 \mathrm{bA}$ & 2.77 & $42.56 \mathrm{aA}$ & 1.63 & 0.03 \\
\hline & Flunixin & 53.65aA & 1.79 & $53.41 \mathrm{aA}$ & 1.94 & $58.52 \mathrm{aA}$ & 2.85 & $50.22 \mathrm{aA}$ & 3.3 & 0.18 \\
\hline & $P$ treatment & 0.99 & & 0.18 & & 0.59 & & 0.15 & & \\
\hline
\end{tabular}

$\mathrm{M}=$ means, $\mathrm{MSE}=$ means square error, ROS = reactive oxygen species; $(\mathrm{A}, \mathrm{B})$ Uppercase letters indicate significance difference between groups, $(\mathrm{a}, \mathrm{b})$ lowercase letters indicate significance difference between the time for each group; Tukey test, $P<0.05$. 
Ketoprofen administered alone before a surgical castration in bovines promotes a lower increase of serum cortisol, acute-phase protein secretion, and higher effectiveness of immune response than local lidocaine administered alone or in combination with ketoprofen (Earley \& Crowe 2002). In contrast, Paull et al. (2007) and Straticò et al. (2018) noted that the combined use of a local anesthetic and NSAIDs was more effective in controlling pain and serum cortisol secretion than the isolated use of NSAIDs in the surgical caudectomy or surgical castration of lambs, because NSAIDs provide a longer period of analgesia, and their systemic effects provide analgesia to damaged tissues that are not accessible to nerve blockade using local anesthetics.

Although most studies that involve research on pain levels measure the serum cortisol levels, we did not measure the levels of serum cortisol because the levels of this hormone have an individual variation (Bertagnon et al. 2017). Sousa et al. (2019) found an increase in the level of cortisol serum in lambs from 2 of 3 groups submitted for the same surgical procedure (castration and implantation of ruminal cannula) before the analgesic protocol reinforcing the hypothesis that cortisol is influenced by the individual response.

Besides this hormone may be influenced by simple manipulations of the animal, such as blood collection, and there were not linear correlations between the magnitude of cortisol response and the severity of these noxious stimuli (Straticò et al. 2018). Similarly, Sousa et al. (2019) and Straticò et al. (2018) noted the increases of serum cortisol levels did not influence blood neutrophils or leukocyte counts. As Marini et al. (2017) and Ballou et al. (2013) used a neutrophilia or neutrophil/lymphocyte ratio as an indicator of pain/stress or inflammation in sheep and calves respectively, we believed this variable can be an indicator of pain or inflammation also.

In cattle and lamb subjected to surgical mulesing or orchiectomy, the most accurate indicator of pain would be the combination of different variables such as the respiratory frequency and pain-related postures and facial expressions (Millman 2013, Marini et al. 2017). Based on this concept, the present study examines the parameters that were most frequently assessed by researchers who have evaluated the pain experienced by sheep submitted to caudectomies, such as the RR, V, EF, and PS (Paull et al. 2007, Guesgen et al. 2016). The lambs from this experiment did not show other abnormal pain behaviors frequently analyzed in surgical mulesing lambs like kicking or foot-stamping, rolling, jumping, licking, or biting would site (Marini et al. 2017).
The increase in the RR observed at the $48 \mathrm{~h}$ time point in comparison to the other time points in all the groups was probably because the lambs perceived the presence of people around them; although these observers were outside the enclosure, this may have influenced this parameter, in addition to the separation of the lambs from their mothers. Both these situations are potentially stressful and may affect this parameter (Millman 2013).

Thus, at the $6 \mathrm{~h}$ time point after the procedure, the animals in the caudectomy groups presented a higher in the RR, V and PS than control group. However, the procedure did not influence the movement of the animals' ears different those observed by Guesgen et al. (2016) but influence the time spent in each ear's posture. Maybe there was no influence ears changes posture because Guesgen et al. (2016) performed surgical caudectomy, a more painful procedure, that can generate pain of a greater magnitude, considered as acute pain.

The pain associated with the procedure we performed may be considered acute and chronic. The acute pain was attenuated during the first hours following the procedure by the local anesthesia, and at the $6 \mathrm{~h}$ time point, it manifested at a lower magnitude than that which is experienced by the surgical cases. Chronic pain observed between 48 and $144 \mathrm{~h}$, is more subjective and may not have been perceived by the methods proposed in our study (Millman 2013).

While quantitative/semi-quantitative methods (RR and EF) are more prone to external interference (Becker et al. 2012), posture assessment is a more subjective technique that may not accurately reflect the signs of chronic pain and stress (Millman 2013). Therefore Bertagnon et al. (2017) suggest that the main identifying parameters of chronic pain are weight loss and changes in health status and immunity. In this way, our measured parameters such as the V, RR, pain-related postures, and blood granulocytes of the animals, indicated the procedure was deleterious to the animals, did not prevent the acute pain or discomfort. It is likely that the effects of the local anesthesia ceased within 2 to 4 h (Ballou et al. 2013) and that the NSAIDs used attenuated but failed to prevent the inflammatory cascade in response to the procedure, thereby interfering with the blood granulocyte function.

Although parameters like weight loss and changes in health status were not evaluated, we believe the ketoprofen was less effective in controlling the chronic pain/discomfort than the flunixin. The ketoprofen group spent more time in abnormal pain posture until $48 \mathrm{~h}$ after the caudectomy and showed a decrease of granulocytes ROS production percentage at the

Table 4. Efficiency of blood granulocytes functions in lambs according the analgesic protocols for caudectomy

\begin{tabular}{|c|c|c|c|c|c|c|c|c|c|c|}
\hline Item & \multirow{2}{*}{ Group } & \multicolumn{2}{|c|}{$-15 \min$} & \multicolumn{2}{|r|}{$6 \mathrm{~h}$} & \multicolumn{2}{|r|}{$48 \mathrm{~h}$} & \multicolumn{2}{|c|}{$144 \mathrm{~h}$} & \multirow{2}{*}{$P$ time } \\
\hline Granulocytes & & ME & $\mathrm{CI}$ & $\mathrm{ME}$ & $\mathrm{CI}$ & ME & $\mathrm{CI}$ & ME & $\mathrm{CI}$ & \\
\hline \multirow{4}{*}{$\begin{array}{l}\text { Phagocytosis FI } \\
\text { (arbitrary values) }\end{array}$} & Control & $1083 a A$ & $878.5-1437.0$ & 790aA & 606.6-1352.5 & $1127 \mathrm{aA}$ & 905.6-1397.2 & $1241 \mathrm{aA}$ & $357.9-4400.3$ & 0.17 \\
\hline & Ketoprofen & $1006 \mathrm{aA}$ & 686.3-1602.2 & $710 \mathrm{bA}$ & $579.0-930.0$ & $975 \mathrm{abA}$ & 846.1-1004.2 & $1651 \mathrm{aA}$ & $842.1-2490.0$ & 0.02 \\
\hline & Flunixin & $1234 \mathrm{aA}$ & $1108.4-1539.3$ & $748 \mathrm{bA}$ & $604.0-1151.9$ & $1275 \mathrm{abA}$ & $975.7-1611.2$ & $2336 a A$ & $1744.2-2926.0$ & 0.0005 \\
\hline & $P$ treatment & 0.24 & & 0.09 & & 0.11 & & 0.62 & & \\
\hline \multirow{4}{*}{$\begin{array}{l}\text { ROS FI } \\
\text { (arbitrary values) }\end{array}$} & Control & $423 a A$ & $367.5-619.2$ & $297 a A$ & $232.0-372.5$ & $372 \mathrm{aA}$ & $278.3-437.3$ & $429 a A$ & $283.0-644.3$ & 0.5 \\
\hline & Ketoprofen & $337 \mathrm{aA}$ & 215.3-598.7 & $222 \mathrm{aA}$ & $90.0-422.7$ & $312 \mathrm{aA}$ & $207.7-413.8$ & $288,5 \mathrm{aA}$ & $62.5-592.8$ & 0.17 \\
\hline & Flunixin & 469aA & $335.0-654.2$ & 309aA & 197.4-392.6 & $349 \mathrm{aA}$ & $264.7-472.5$ & $455 \mathrm{aA}$ & $324.5-556.2$ & 0.28 \\
\hline & $P$ treatment & 0.2 & & 0.39 & & 0.52 & & 0.28 & & \\
\hline
\end{tabular}

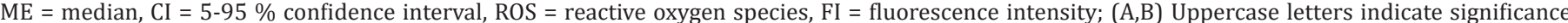
difference between groups, $(\mathrm{a}, \mathrm{b})$ lowercase letters indicate significance difference between the time for each group; Dunn test, $P<0.05$. 
144h. Among the immune innate functions, the most important is the phagocytosis of antigenic particles and their intracellular elimination by enzymes and cytoplasmic granules, and the ROS production being highlighted as the most important (Belló et al. 2015). So the decrease of this function of the blood granulocytes indicate an impaired of the innate immune system.

Similarly, Paull et al. (2008) and Sousa et al. (2019) also noted that ketoprofen was less effective in controlling mulesing or orchiectomy and implantation of ruminal cannula pain in lambs than flunixin meglumine. According to Sousa et al. (2019), the animals of the ketoprofen group isolated themselves from the others and remained in an antialgic position in relation to the groups that received flunixin meglumine, although both groups maintained the same serum cortisol levels. According to Paull et al. (2008), the animals that received ketoprofen remained longer in antialgical posture and had higher cortisol levels than the groups that received flunixin meglumine after mulesing. Possibly these effects are due to the faster elimination of ketoprofen, in comparison to flunixin meglumine (Sousa et al. 2019). Additionally, the dose used in our study was twice the dose of flunixin meglumine used by Sousa et al. (2019), and the same dose used by Paull et al. (2008), which may have a greater analgesic effect.

\section{CONCLUSION}

The flunixin meglumine and ketoprofen did not prevent the acute pain or discomfort experienced by neonatal lambs subjected to caudectomy by ring rubber, but the flunixin meglumine, was more effective in controlling the chronic pain/discomfort than the ketoprofen.

Acknowledgements.- Funding for this research was supported by PIBIC/“Fundação Araucária-Paraná”, Brazil Government. This study was financed in part by the "Coordenação de Aperfeiçoamento de Pessoal de Nível Superior” (CAPES), Brazil, Finance Code 001.

Conflict of interest statement.- The authors have no competing interests.

\section{REFERENCES}

Aro D.T., Polizer K.A. \& Pena S.B. 2007. 0 agronegócio na ovinocultura de corte no Brasil. Revta Cient. Med. Vet. 5(9):1-6.

Ballou M.A., Sutherland M.A., Brooks T.A., Hulbert L.E., Davis B.L. \& Cobb C.J. 2013. Administration of anesthetic and analgesic prevent the suppression of many leukocyte responses following surgical castration and physical dehorning. Vet. Immunol. Immunop.151(3/4):285-293. <https://dx.doi. org/10.1016/j.vetimm.2012.11.018><PMid:23270586>

Becker J., Doherr M.G., Bruckmaier R.M., Bodmer M., Zanolari P. \& Steiner A. 2012. Acute and chronic pain in calves after different methods of rubberring castration. Vet. J. 194(3):380-385. <https://dx.doi.org/10.1016/j. tvjl.2012.04.022><PMid:22647596>

Bellinazzi J.B., Bertagnon H.G., Batista C.F., Santos B.P., Lima M.G.B., Lima D.M., Benesi F.J. \& Della Libera A.M.M. 2013. Effects of the stress of orchectomy on bronchoalveolar citology of Holstein calves. Pesq. Vet. Bras. 33(Supl.1):9398. <https://dx.doi.org/10.1590/S0100-736X2013001300015>

Belló C., Schemberger J.A, Machado W.M., Fernandes D. \& Vellosa J.C.R. 2015. 0 cetoprofeno como oportunidade terapêutica no estresse oxidativo: uma revisão. Revta Ciênc. Farm. Básica Apl. 36(1):123-129.

Bertagnon H.G., Batista C.F., Santos B.P., Lima M.G.B., Bellinazzi J.B. \& Della Libera A.M.M.P. 2017. Influence of orchiectomy of seven month old bulls on bronchoalveolar immune function. Arq. Bras. Med. Vet. Zootec. 69(2):310316. <https://dx.doi.org/10.1590/1678-4162-9214>
Earley B. \& Crowe M.A. 2002. Effects of ketoprofen alone or in combination with local anesthesia during the castration of bull calves on plasma cortisol, immunological, and inflammatory responses. J. Anim. Sci. 80(4):10441052. <https://dx.doi.org/10.2527/2002.8041044x><PMid:12002311>

Fisher M.W., Gregory N.G., Kent J.E., Scobie D.R., Mellor D.L. \& Pollard J.C. 2004. Justifying the appropriate length for docking lambs tails: a review of the literature. Proceedings New Zealand Society of Animal Production 64:293-296.

Grant C. 2004. Behavioral responses of lambs to common painful husbandry procedures. Appl. Anim. Behav. Sci. 87(3/4):255-273. <https://dx.doi. org/10.1016/j.applanim.2004.01.011>

Guesgen M.J., Beausoleil N.J. \& Minot E.O. 2016. Lambs show changes in ear posture when experiencing pain. Anim. Welfare 25(2):171-177. <https:// dx.doi.org/10.7120/09627286.25.2.171>

Kampen A.H., Tollersrud T. \& Lund A. 2004. Flow cytometric measurement of neutrophil respiratory burst in whole bovine blood using live Staphylococcus aureus. J. Immunol. Meth. 289(1/2):47-55. < https://dx.doi.org/10.1016/j. jim.2004.03.008>

Kent J.E., Thrusfield M.V., Molony V., Hosie B.D \& Sheppard B.W. 2004. Randomized, controlled field trial of two new techniques for the castration and tail docking of lambs less than two days of age. Vet. Rec. 154(7):193200. <https://dx.doi.org/10.1136/vr.154.7.193> <PMid:14994857>

Lomax S., Sheil M. \& Windsor P. 2013. Duration of action of a topical anaesthetic formulation for pain management of mulesing in sheep. Aust. Vet. J. 91(4):160-167. <https://dx.doi.org/10.1111/avj.12031><PMid:23521101>

Marini D., Colditz I.G., Hinch G., Petherick J.C. \& Lee C. 2017. Self-administration by consumption of flunixin in feed alleviates the pain and inflammation associated with castration and tail docking of lambs. Appl. Anim. Behav. Sci. 188:26-33. <https://dx.doi.org/10.1016/j.applanim.2016.12.008>

Mellor D.J. \& Stafford K.J. 2000 Acute castration and/or tailing distress and its alleviation in lambs. New Zealand Vet. J. 48(2):33-43. <https://dx.doi. org/10.1080/00480169.2000.36156> <PMid:16032116>

Millman T.S. 2013. Behavioral responses of cattle to pain and implications for diagnosis, management, and animal welfare. Vet. Clin. N. Am., Large Anim. Pract. 29(1):47-58. <https://dx.doi.org/10.1016/j.cvfa.2012.11.007> <PMid:23438399>

Paull D.R., Colditz I.G., Lee C., Atkinson S.J. \& Fisher A.D. 2008. Effectiveness of non-steroidal anti-inflammatory drugs and epidural anaesthesia in reducing the pain and stress responses to a surgical husbandry procedure (mulesing) in sheep. Aust. J. Exp. Agric. 48:1034-1039. <https://dx.doi. org/10.1071/EA08050>

Paull D.R., Lee C., Colditz I.G., Atkinson S.J. \& Fisher A.D. 2007. The effect of a topical anaesthetic formulation, systemic flunixin and carprofen, singly or in combination, on cortisol and behavioural responses of Merino lambs to mulesing. Aust. Vet. J. 85(3):98-106. <https://dx.doi. org/10.1111/j.1751-0813.2007.00115.x><PMid:17359309>

Small A.H., Marini D., le Floch M., Paull D. \& Lee C. 2018. A pen study evaluation of buccal meloxicam and topical anaesthetic at improving welfare of lambs undergoing surgical mulesing and hot knife tail docking. Res. Vet. Sci. 118:270-277. <https://dx.doi.org/10.1016/j.rvsc.2018.02.011>

Sousa R.S., Sousa I.K.F., Reis L.F., Rodrigues F.A.L.M., Minervino A.H.H., Mori C.S., Moreira A.P., Paula V.V., Barreto Júnior R.A. \& Ortolani E.L. 2019. Avaliação de anti-inflamatórios não esteroidais no tratamento da dor de ovinos submetidos à implantação de cânula ruminal e orquiectomia. Arq. Bras. Med. Vet. Zootec. 71(4):1316-1326. <https://dx.doi.org/10.1590/1678-4162-9871>

Straticò P., Varasano V., Suriano R., Mariscoli M., Robbe D., Giammarco M., Vignola G. \& Petrizzi L. 2018. Analgesic effects of intravenous flunixin and intrafunicular lidocaine or their combination for castration of lambs. Vet. Rec. Open 5(1):e000266. <https://dx.doi.org/10.1136/vetreco-2017-000266> $<$ PMid:30018767>

Tornquist S.J. \& Rigas J. 2010. Interpretation of ruminant leukocyte responses, p.307-313. In: Weiss D.J. \& Wardrop K.J. (Eds), Schalm's Veterinary Hematology. 6th ed. Blackwell Publishing Ltd., Iowa. 